\title{
SOURgrass Densities AfFecting the Initial Growth and Macronutrient Content of Coffee Plants ${ }^{1}$
}

\author{
Densidades de Capim-Amargoso Afetando o Crescimento Inicial e o Teor de Macronutrientes do \\ Cafeeiro
}

\author{
CARVALHO, L.B. ${ }^{2}$, ALVES, P.L.C.A. ${ }^{3}$, and BIANCO, S. ${ }^{3}$
}

\begin{abstract}
The objective of this work was to evaluate the coexistence effects of coffee (Coffea arabica) with densities of sourgrass (Digitaria insularis) on crop macronutrient content and plant growth. The experiment was conducted in plots where one coffee plant was maintained in coexistence with $\mathrm{O}$ (weed-free check), 1, 2, 4, 8, and 16 sourgrass plants, using a completely randomized design with three replicates. Reduction of coffee growth and macronutrient content, except $\mathrm{P}$ that increased, started when the coexistence occurred with sourgrass plants in a density of 1 plant per plot. In general, macronutrient content was reduced by $18-50 \%$, while growth characteristics were reduced by $9-41 \%$, when coffee plants coexisted with 16 plants of sourgrass. Thus, sourgrass competition for nutrients was a strong factor limiting coffee plant growth.
\end{abstract}

Keywords: Coffea arabica, Digitaria insularis, competition, additive experiment, nutrients

\begin{abstract}
RESUMO-O objetivo deste trabalho foi avaliar os efeitos da convivência do cafeeiro (Coffea a rabica) com densidades de capim-amargoso (Digitaria insularis) sobre o teor de macronutrientes e o crescimento das plantas da cultura. O experimento foi conduzido em caixas enterradas no solo, onde uma planta de café foi mantida em convivência com O (testemunha livre de plantas daninhas), 1, 2, 4, 8 e 16 plantas de capim-amargoso, usando o delineamento inteiramente casualizado com três repetições. A redução no crescimento e no teor de macronutrientes do cafeeiro-exceto $P$, que aumentou-iniciouse quando a convivência ocorreu com plantas de capim-amargoso na densidade de uma planta por caixa. Em geral, o teor de macronutrientes foi reduzido em 10-50\%, enquanto as caracteristicas de crescimento foram reduzidas em 9-41\%, quando o cafeeiro conviveu com 16 plantas de capim-amargoso. Assim, a competição de capim-amargoso por nutrientes foi um forte fator limitante para o crescimento das plantas de café.
\end{abstract}

Palavras-chave: Coffea arabica, Digitaria insularis, competição, experimento aditivo, nutrientes.

\section{INTRODUCTION}

Weed interference is a very important issue in coffee production (Lemes et al., 2010). Weeds can reduce plant height, stem diameter, number of leaves, leaf area, and dry mass of coffee plants (Oliveira et al., 2005; Ronchi \& Silva, 2006; Marcolini et al., 2009). Reduction in nutrients content and accumulation of coffee plants were also noted (Ronchi et al., 2003, 2007). As a final consequence of weed interference, yield reduction by more than $70 \%$ was found when coffee plants coexisted with weeds throughout the production season (Alcântara \& Ferreira, 2000; Alcântara et al., 2007; Dias et al., 2008; Lemes et al., 2010).

Recebido para publicação em 2.8.2012 e aprovado em 26.10.2012.

2 Prof. Adjunto do Dep. de Agronomia do Centro de Ciências Agroveterinárias, Universidade do Estado de Santa Catarina - CAV/ UDESC, 88520-000 Lages-SC, Brasil, <lbcarvalho@cav.udesc.br>; ${ }^{3}$ Faculdade de Ciências Agrárias e Veterinárias, Universidade Estadual Paulista - FCAV/UNESP, 14884-900 Jaboticabal-SP, Brasil, <plalves@fcav.unesp.br>,<sbianco@fcav.unesp.br> 
Young coffee plants are very susceptible to weed interference after being planted in the fields, due to their low initial growth (Silva \& Ronchi, 2003; Lemes et al., 2010). Digitaria insularis, commonly known as sourgrass weed, is significantly affecting coffee plantations in Brazil (Lemes et al., 2010; Carvalho et al., 2011). This weed grows quickly in warm and rainy season, when coffee seedlings are most commonly planted. Thus, sourgrass coexistence with young coffee plants can provide a very high competition for environmental resources, so that substantial crop initial growth reduction can occur with reflects on coffee production.

The most commonly used methodology to estimate weed interference potential on crops has been the additive experiment. In that experiment, crop density is maintained constant, while weed density is increased, so that crop is used as a comparative indicator for weed competitiveness and aggressiveness (Jolliffe et al., 1984; Radosevich et al., 1997).

There is a hypothesis that increased sourgrass densities, when it is in coexistence with young coffee plants after planting, could negatively influence both macronutrient uptake and initial growth of coffee plants. The objective of this work was to evaluate the coexistence effects of coffee plants with increased densities of sourgrass on crop macronutrient content and growth characteristics, after crop planting.

\section{MATERIAL AND METHODS}

The experiment was carried out in plots buried in the ground, showing surface area of approximately $0.5 \mathrm{~m}^{2}$, and depth of $1.50 \mathrm{~m}$, in Brazil, at $21^{\circ} 15^{\prime} 22^{\prime \prime} \mathrm{S}$ and $48^{\circ} 18^{\prime} 58^{\prime \prime} \mathrm{W}$, from March to July, 2009. Plots were filled with Red Latosol clay textured substrate. Substrate was fertilized with two liters of manure per plot, incorporated to substrate in $10 \mathrm{~cm}$ depth just a week before crop planting. NPK fertilizer was also supplied at $80 \mathrm{~g}$ per plots in the time of crop planting. Pesticides were applied preventively every fourteen days. Water was daily supplied, except in rainy days.

Treatments consisted of the coexistence of 1 coffee plant per plot with different densities $(1,2,4,8$, and 16 plants per plot, simulating a range of densities from 2 up to 36 plants per square meters in field conditions) of sourgrass plants, with continuous weed-free check. Coffee seedlings of Coffea arabica cultivar Catuai Vermelho IAC-144 was planted in the center of each plot; while sourgrass seedlings were randomly planted surrounding the coffee plant in each plot. Treatments were arranged in a completely randomized design with seven replicates.

At 108 days after crop planting, sourgrass plants were cut off and dried in a forced air-convection oven at $70{ }^{\circ} \mathrm{C}$ for $96 \mathrm{~h}$. At the same time, coffee plant growth was evaluated, by measuring plant height and stem diameter. After that, coffee plants were cut off, the number of leaves was found (manually counted), as well as total leaf area (Li-Cor Inc., LI3000A, USA). Then, stem and leaves were also dried separately in a forced air-convection oven at $70{ }^{\circ} \mathrm{C}$ for $96 \mathrm{~h}$. After drying, sourgrass and coffee shoot dried materials were weighted to determine dry mass.

In addition, macronutrients were extracted from coffee shoot dried material by semi-micro Kjedahl method $(\mathrm{N})$, colorimetric method $(\mathrm{P})$, atomic absorption spectrophotometry $(\mathrm{K}, \mathrm{Ca}$, and $\mathrm{Mg}$ ), and turbidimetric method (S), as by Carvalho et al. (2010).

All data were submitted to non-linear regression analysis using SigmaPlot (Systat Software, version 10.0, USA).

\section{RESULTS AND DISCUSSION}

Sourgrass total shoot dry mass increased exponentially when weed density was increased (Figure 1). A sourgrass population of 16 plants accumulated $245.4 \%$ more dry mass than just 1 sourgrass plant growing in coexistence with coffee plant. Opposite response was observed for sourgrass individual shoot dry mass that decreased exponentially by $74.7 \%$ in the density of 16 plants compared to 1 plant per plot.

There is evidence of sourgrass intraspecific interference when a non-linear augment of total dry mass accumulation is examined (Figure 1). It occurred due to a decrease of individual dry mass when weed density was increased (Jolliffe et al., 1984; Radosevich et al., 1997). Decreased growth occurs due to 

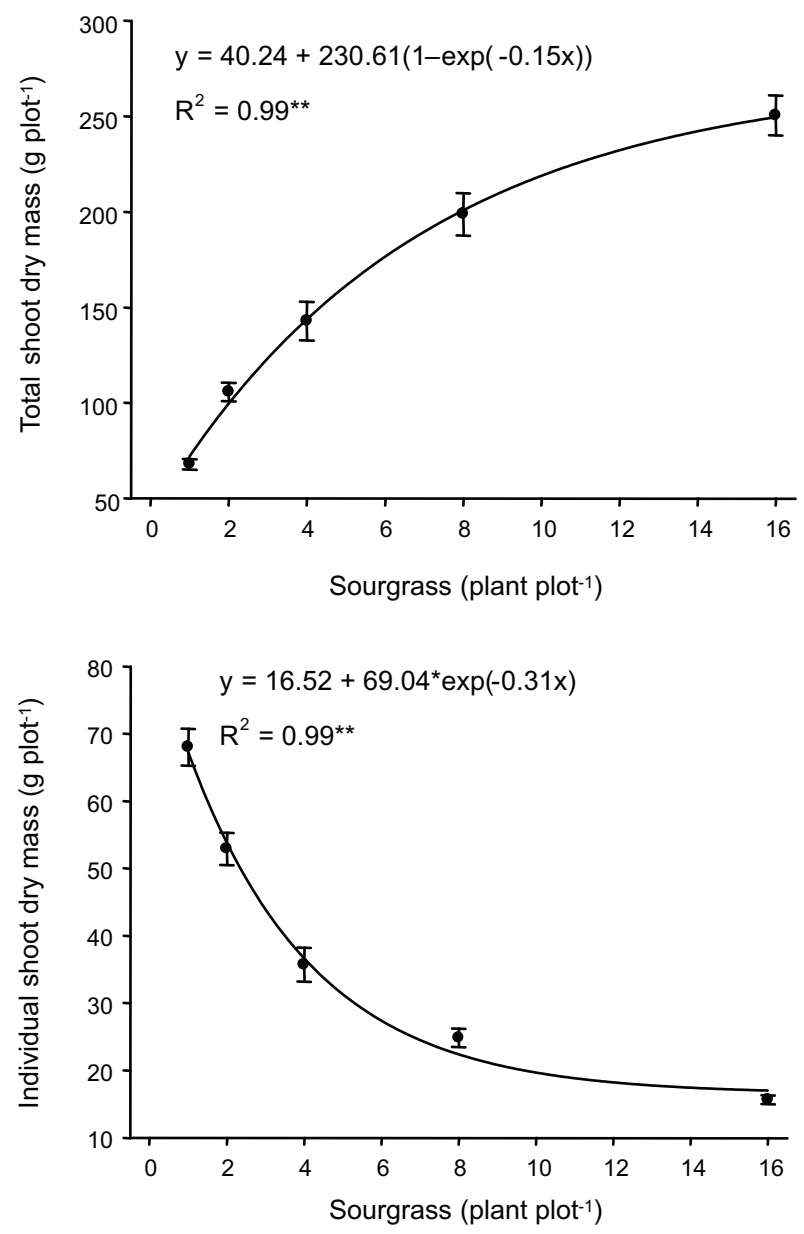

Figure 1 - Total- and individual shoot dry mass of sourgrass plants growing in coexistence with one coffee plant. Vertical lines indicate \pm standard error of the mean. Plot shows surface area of $0.5 \mathrm{~m}^{2}$. Jaboticabal-SP, Brazil, 2009.

a lower environmental resource allocation by plant growth individually and reflects on population growth (Radosevich et al., 1997). However, sourgrass did not attain a final constant dry mass production, which is critical for intraspecific interference. At this point, dry mass accumulation becomes constant even if density is increased (Jolliffe et al., 1984; Radosevich et al., 1997). So, we can point out that sourgrass increased its potential of interference on coffee plantation from 1 to 16 plants per plot.

Coffee plant height, stem diameter, number of leaves, and leaf area reduced exponentially when sourgrass density increased (Figure 2). Plant height, number of leaves, and leaf area reduced by $9.2 \%, 43.3 \%$, and
$39.1 \%$ when coffee plant was grown in coexistence with 16 sourgrass plants. Stem diameter reduced by $9.4 \%$, but was kept constant after the density of 8 sourgrass plants per plot.

Coffee growth characteristics related to leaf development, such as number of leaves and leaf area, were highly reduced when coffee characteristics related to stem development, such as plant height and stem diameter, were poorly reduced (Figure 2). It suggests that leaves were more susceptible to sourgrass interference than coffee stem. That result corroborates observations of Marcolini et al. (2009) in coffee plantations. Toledo et al. (2001) and Dinardo et al. (2003) concluded that leaves are the most susceptible plant organs to effects of increasing weed density. That fact occurs due to a lower leaf emission or/and premature leaf falling when crops grow in coexistence with weeds.

Coffee stem and leaves dry mass reduced exponentially when sourgrass density was increased (Figure 3). Stem and leaves dry mass reduced by $20.6 \%$ and $41.0 \%$, respectively, when coffee plant was grown in coexistence with 16 sourgrass plants. Reduction of dry mass of leaves was more intense and faster than stem reduction, so that difference between leaves and stem dry mass reduction support the affirmation above.

Reduction of coffee dry mass accumulation occurred probably due to decreased capacity of light and $\mathrm{CO}_{2}$ uptake as a consequence of leaf area reduction that reflects on the global plant photosynthesis. According to Engel \& Poggiani (1990), total dry mass accumulated by plants depends on their global photosynthesis. Thus, we can emphasize that global crop photosynthesis should be reduced when weed density increased and, as a function of this, plant growth reduced despite of the fact that net assimilation rate (photosynthetic efficiency) had increased linearly when sourgrass density increased (data not shown). Reduction of crop dry mass production was also found by Marcolini et al. (2009).

Rates of N, K, Ca, Mg, and S in coffee plant decreased exponentially when sourgrass density was increased (Figure 4). Coffee N rate reduced by $24.3 \%$, but was kept constant 

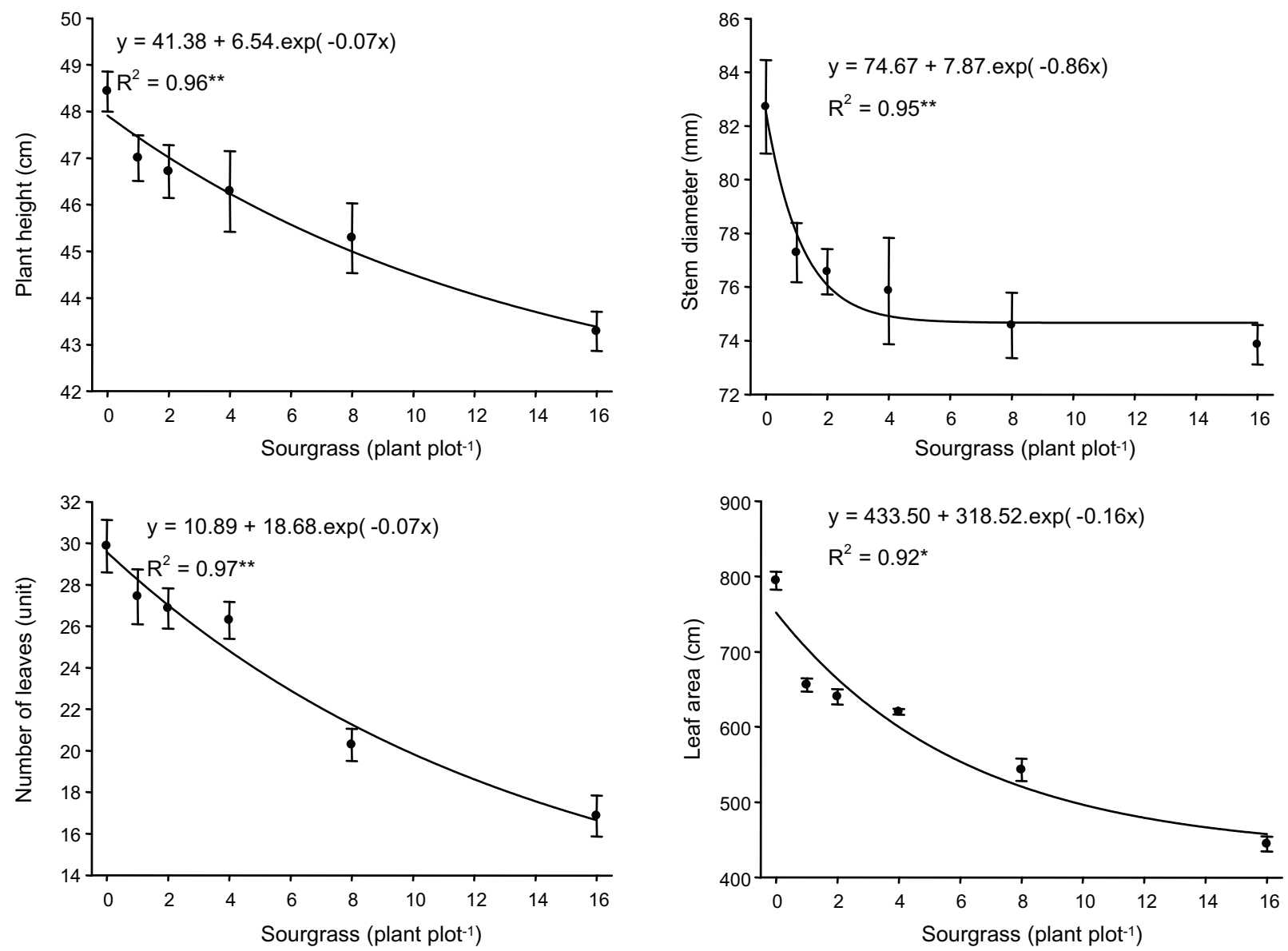

Figure 2 - Plant height, stem diameter, number of leaves and leaf area of coffee plants growing under coexistence with increased densities of sourgrass. Vertical lines indicate \pm standard error of the mean. Plot shows surface area of $0.5 \mathrm{~m}^{2}$. Jaboticabal-SP, Brazil, 2009
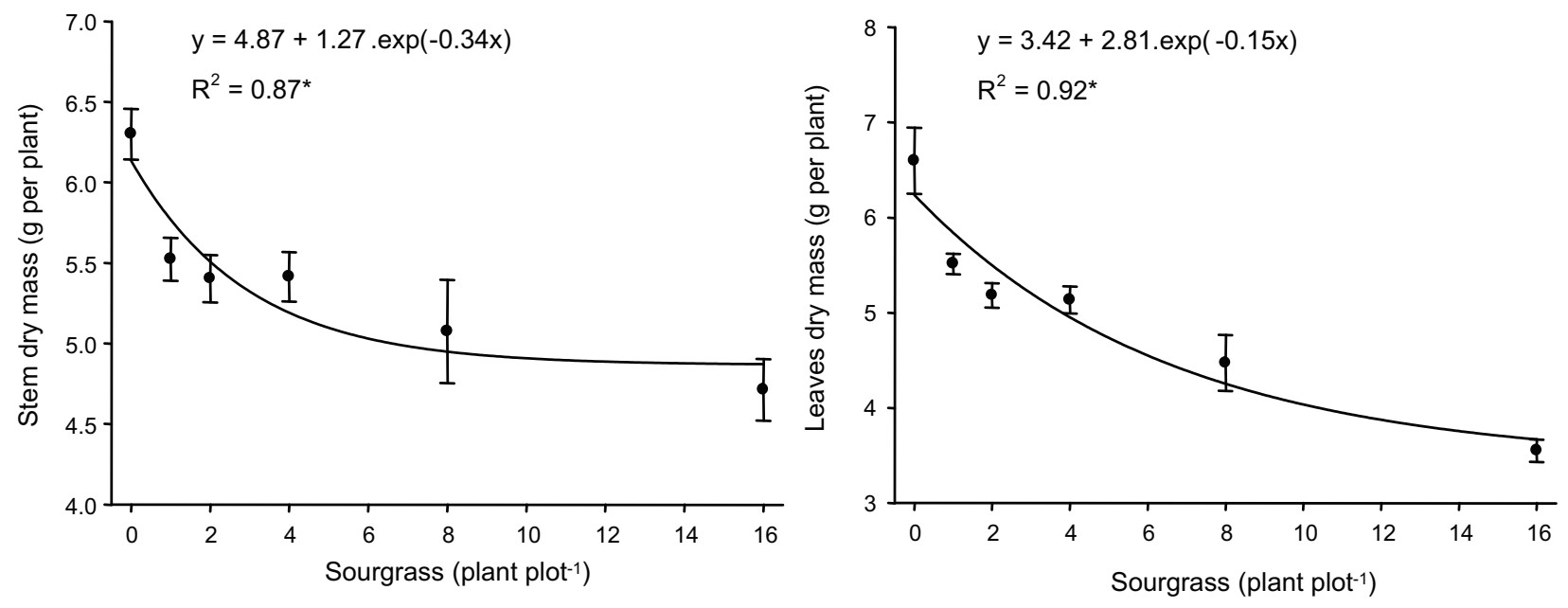

Figure 3 - Dry mass of stem and leaves of coffee plants growing under coexistence with increased densities of sourgrass. Vertical lines indicate \pm standard error of the mean. Plot shows surface area of $0.5 \mathrm{~m}^{2}$. Jaboticabal-SP, Brazil, 2009. 
after the density of 12 sourgrass plants. Rates of $\mathrm{K}, \mathrm{Ca}$, and $\mathrm{Mg}$ reduced by $8.0 \%, 21.7 \%$, and $17.2 \%$ when coffee plant was grown in coexistence with 16 sourgrass plants. Rate of $\mathrm{S}$ reduced by $18.1 \%$, but was kept constant after the density of 8 sourgrass plants.
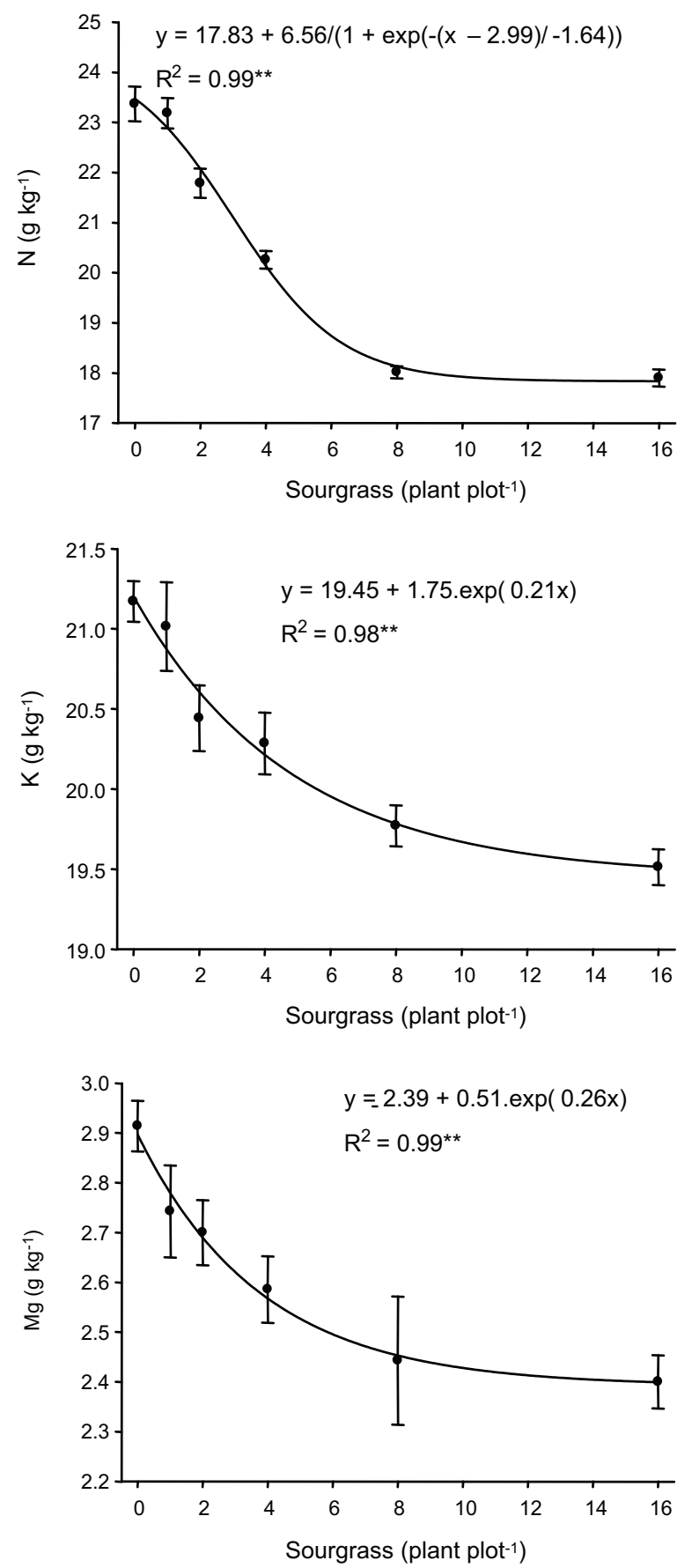

Opposite response was verified for $\mathrm{P}$ rate that increased exponentially when sourgrass density was increased. Compared to the weedfree check, $\mathrm{P}$ rate increased by $10.8 \%$ when coffee plant was grown with 16 plants of sourgrass.
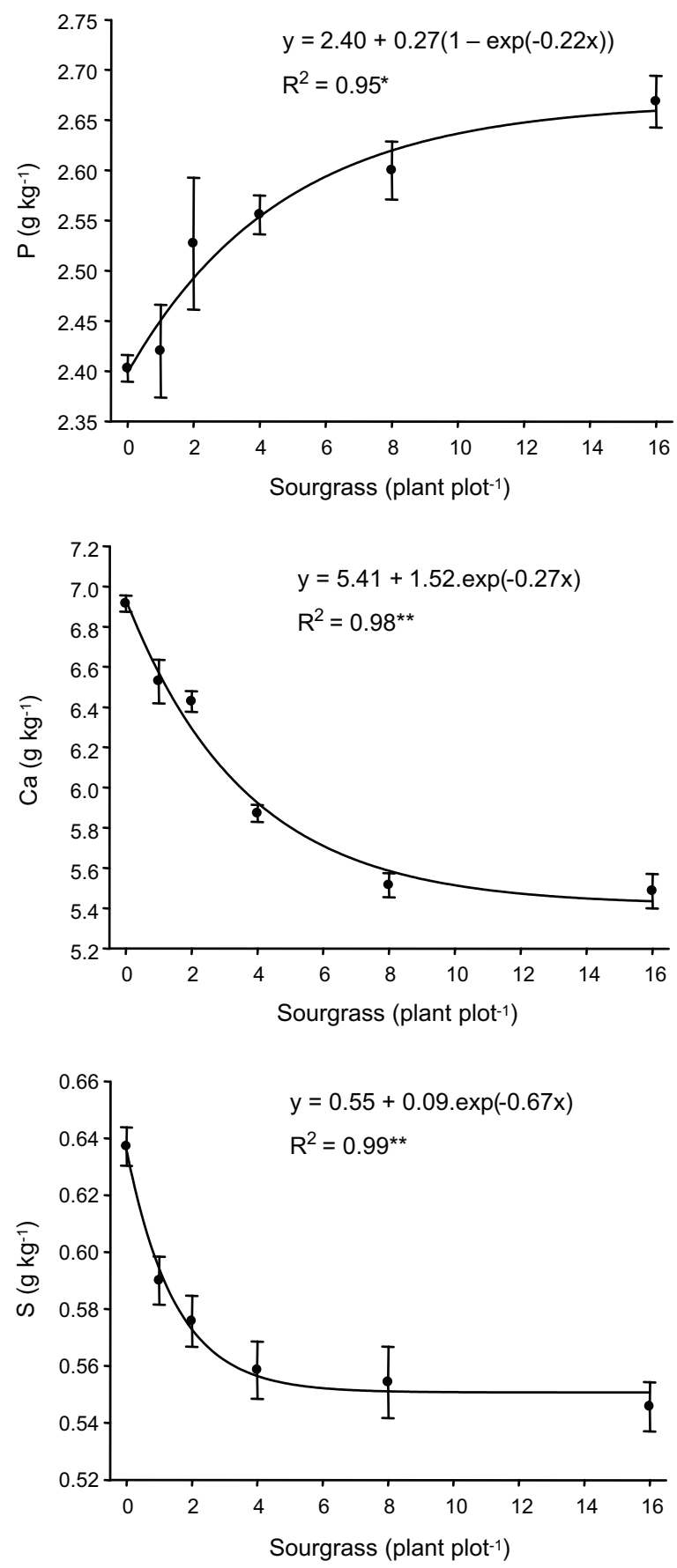

Figure 4 - Rate of macronutrients in coffee plants growing under coexistence with increased densities of sourgrass. Vertical lines indicate \pm standard error of the mean. Plot shows surface area of $0.5 \mathrm{~m}^{2}$. Jaboticabal-SP, Brazil, 2009. 
Macronutrient rates (except $\mathrm{P}$ ) decreased when sourgrass density was increased (Figure 3 ). It suggests that those macronutrients were limited for coffee plant uptake and then influenced on coffee growth. Ronchi et al. (2007) concluded that competition for nutrients reduced coffee initial growth, delaying plant establishment and maturity, but, according to Ronchi et al. (2003), growth reduction intensity depended on the weed species. In general, weeds are more competitive for nutrients than crops (Ronchi et al., 2003, 2007), suggesting that nutrition is an important factor in the evaluation of weed-crop interaction.

For P response, we found that a mycorrhizal association between coffee plant and soil fungi can explain P increase. Colozzi Filho \& Cardoso (2000) and Tristão et al. (2006) observed that association. Smith \& Read (1997) reported a mycorrhizal association between coffee and grasses. That association could increase crop nutrient uptake from soils under Urochloa decumbens infestation (Silva et al., 2006). It suggests that same association can occur between coffee plants and sourgrass. A most notably benefic effect of that association is an augment in low soluble nutrients, such as $\mathrm{P}, \mathrm{Zn}$ and $\mathrm{Cu}$ (Chu, 2005). Colozzi Filho \& Nogueira (2007) proved that mycorrhizal can increase mineral phosphate solubilization in the soil. Thus, coffee P rate had been increased, because it was more available for crop uptake provided by phosphor solubilization in the soil.

In short, sourgrass increased its potential of interference, while coffee plants decreased their potential of growing, when weed density increased, providing a high reduction of coffee macronutrients uptake (except P) and crop growth. According to the results, a high plant growth and content of macronutrients reduction started when coffee plants coexisted with two plants of sourgrass per square meters. Thus, sourgrass must be controlled, even at low densities, in coffee plantations to prevent weed competition for nutrients and other environmental resources, because initial crop growth can decrease. Moreover, crop establishment and time to reach maturity can delay, probably also reducing their bearing capacity. Thus, sourgrass competition for nutrients is a strong factor limiting coffee plant growth.

\section{ACKNOWLEDGEMENTS}

The authors would like to thank CNPq in Brazil for the financial scholarship support provided to the first author.

\section{LITERATURE CITED}

ALCÂNTARA, E. M; FERREIRA, M. M. Efeito de diferentes métodos de controle de plantas daninhas sobre a produção de cafeeiros instalados em Latossolo roxo distrófico. Ci. Agrotec., v. 24, n. 1, p. 54-61, 2000.

ALCÂNTARA, E. M.; NÓBREGA, J. C. A.; FERREIRA, M. M. Métodos de controle de plantas invasoras na cultura do cafeeiro (Coffea arabica L.) e componentes da acidez do solo. R. Bras. Ci. Solo, v. 31, n. 6, p. 1525-1533, 2007.

CARVALHO, L. B.; BIANCO, S.; GUZZO, C. D. Interferência de Euphorbia heterophylla no crescimento e acúmulo de macronutrientes da soja. Planta Daninha, v. 28, n. 1, p. $33-39,2010$

CARVALHO, L. B. et al. Detection of sourgrass (Digitaria insularis) biotypes resistant to glyphosate in Brazil.

Weed Sci., v. 59, n. 2, p. 171-176, 2011.

CHU, E. Y. Sistema de produção: pimenteira-do-reino. Micorriza. Embrapa, 2005. Disponível em: <http:// sistemasdeproducao.cnptia.embrapa.br/FontesHTML/ Pimenta/PimeiteiradoReino/paginas/micorrizas.htm $>$. Acesso em: 8 nov. 2010.

COLOZZI FILHO, A.; CARDOSO, E. J. B. N. Detecção de fungos micorrízicos arbusculares em raízes de cafeeiro e de crotalária cultivada na entrelinha. Pesq. Agropec. Bras., v. 35, n. 10, p. 2033-2042, 2000.

COLOZZI FILHO, A.; NOGUEIRA, M. A. Micorrizas arbusculares em plantas tropicais: café, mandioca e cana-deaçúcar. In: SILVA, A. P. D.; FREITAS, S. S. (Eds.).

Microbiota do solo e qualidade ambiental. Campinas: IAC, 2007. p. 39-56.

DIAS, T. C. S.; ALVES, P. L. C. A.; LEMES, L. N. Faixas de controle de plantas daninhas e seus reflexos na produção do cafeeiro. Científica, v. 36, n. 1, p. 81-85, 2008.

DINARDO, W. et al. Efeito da densidade de plantas de Panicum maximum Jacq. sobre o crescimento inicial de Eucalyptus grandis W.Hill ex Maiden. Sci. Flor., v. 64, n. 1, p. 59-68, 2003.

ENGEL, V. L.; POGGIANI, F. Influência do sombreamento sobre o crescimento de mudas de algumas essências nativas e implicações ecológicas e silviculturais. Sci. Flor., v. 43/44, p. $1-10,1990$. 
JOLLIFFE, P. A.; MINJAS, A. N.; RUNECKLES, V. C. A reinterpretation of yield relation-ships in replacement series experiments. J. Appl. Ecol., v. 21, n. 1, p. 227-243, 1984.

LEMES, L. N. et al. Weed interference on coffee fruit production during a four-year investigation after planting. African J. Agric. Res., v. 5, n. 10, p. 1138-1143, 2010.

MARCOLINI, L. W. et al. Effect of density and the distance of Brachiaria decumbens Staff on the initial growth of Coffea arabica. Coffee Sci., v. 4, n. 1, p. 11-15, 2009.

OLIVEIRA, A. R.; FREITAS, S. P.; VIEIRA, H. D. Interferência de trapoerabas no desenvolvimento de mudas de café. Agronomy, v. 39, n. 1, p. 17-21, 2005.

RADOSEVICH, S. R.; HOLT, J.; GUERSA, C. Weed ecology: implication for managements. New York: John Wiley \& Sons, 1997. 589 p.

RONCHI, C. P.; SILVA, A. A. Effects of weed species competition on the growth of young coffee plants.

Planta Daninha, v. 24, n. 3, p. 415-423, 2006.

RONCHI, C. P.; TERRA, A. A.; SILVA, A. A. Growth and nutrient concentration in coffee root system under weed species competition. Planta Daninha, v. 25, n. 4, p. 679-687, 2007.
RONCHI, C. P. et al. Acúmulo de nutrientes pelo cafeeiro sob interferência de plantas daninhas. Planta Daninha, v. 21, n. 2, p. 219-227, 2003.

SILVA, A. A.; RONCHI, C. P. Avanços nas pesquisas sobre o controle de plantas daninhas na cultura do café. In: ZAMBOLIM, L. (Ed.). Produção integrada de café. Viçosa, MG: Universidade Federal de Viçosa, 2003. p. $103-132$.

SILVA, S.; SIQUEIRA, J. O.; SOARES, C. R. F. S. Fungos micorrízicos no crescimento e na extração de metais pesados pela braquiária em solo contaminado. Pesq. Agropec. Bras., v. 41, n. 12 , p. $1749-1757,2006$.

SMITH, S. E.; READ, D. J. Mycorrhizal symbiosis. London: Academic Press, 1997. 589 p.

TOLEDO, R. E. B. et al. Efeito da densidade de plantas de Brachiaria decumbens Stapf sobre o crescimento inicial de mudas de Eucalyptus grandis W. Hill ex. Maiden. Sci. For., v. 60 , n. 1, p. 109-117, 2001.

TRISTÃO, F. S. M.; ANDRADE, S. A. L.; SILVEIRA, A. P. D. Fungos micorrízicos arbusculares na formação de mudas de cafeeiro, em substratos orgânicos comerciais. Bragantia, v. 65, n. 4 , p. $649-658,2006$. 